\title{
The Role of Hyaluronan in Cartilage
}

\author{
軟骨でのヒアルロン酸の役割
}

\author{
Matsumoto, Kazu \\ Department of Orthopedic Surgery, Gifu University School of Medicine, Gifu City, Gifu 501-1194, Japan \\ FAX: 81-58-230-6334, E-mail: mkazuu@gifu-u.ac.jp
}

(Received on March 7, 2010, accepted on April 26, 2010)

Key Words: hyaluronan, hyaluronan synthase (Has), cartilage, CD44, aggrecan

\begin{abstract}
Hyaluronan (HA) is a large, linear polymer of repeating disaccharide units composed of $N$-acetyl-D-glucosamine and D-glucuronic acid. Although HA has a very simple structure, it plays a key role in tissue organization and homeostasis through its physicochemical properties and its interactions with binding proteins and/or specific cell surface receptors.

Recently, using Prx 1 -Cre transgenic mice, we generated conditional knockout mice, in which the Has 2 gene was limb bud mesoderm-specific inactivated. In this review, we describe the role of HA during limb morphogenesis, which was analyzed in Has 2 conditional knockout mice crossed with Prx1-Cre. We further discuss the biochemical and genetic studies of proteoglycan aggregates, which are mainly composed of HA, aggrecan, and link protein. We also focus briefly on the role of CD44, which is a major cell surface receptor of HA. Although much is known about the function of HA, much remains to be learned about how HA is regulated and/or how HA regulates tissue homeostasis. We hope this review provides an important opportunity to consider the roles of HA and that it may prove helpful in understanding the function of HA.
\end{abstract}

\section{A. Introduction}

Hyaluronan (HA) is a large, linear polymer of repeating disaccharide units composed of $\mathrm{N}$-acetyl-D-glucosamine and D-glucuronic acid (1). The number of repeat disaccharides in the HA molecule can reach more than 10,000, and the molecular weight ranges from $10^{3}$ to $10^{4} \mathrm{kDa}$. HA is a structural component of the extracellular matrix (ECM) in a variety of tissues and plays a key role in tissue organization and homeostasis, including angiogenesis, branching morphogenesis, cell migration, and cell proliferation (2-4).

HA has a pronounced hydrophilic capacity and it can form viscoelastic meshworks that are believed to facilitate cell proliferation and migration $(5,6)$. Although several functions of HA may be attributable to its physicochemical
要 約

ヒアルロン酸は $N$ - アセチル - D グルコサミンと D- グルク ロン酸の 2 糖繰り返し構造からなる線状大分子ポリマー構造 の分子である。ヒアルロン酸は非常に単純な構造を持ってい るが、その機能は、ヒアルロン酸の持つ物性そのものの機能 だけでなく、ヒアルロン酸結合タンパクや特異的な細胞表面 のレセプターを介して組織の統制や恒常性維持に重要な働き を演じている。

最近、我々はP Prx1-Cre トランスジェニックマウスを用い てHas2 遺伝子肢芽特異的ノックアウトマウスを作成した。こ の総説では、我々が作製したHas2 遺伝子肢芽特異的ノックア ウトマウスの結果をもとに、軟骨でのヒアルロン酸の役割に ついて述べる。我々はさらにヒアルロン酸、アグリカン、リ ンクタンパクからなるプロテオグリカン会合体についての生 化学的・遺伝学的研究について、また、ヒアルロン酸の代表 的な細胞表面レセプターである CD44の役割についても簡潔 に述べる。ヒアルロン酸は多くの機能が知られているが、ヒ アルロン酸はどのように調節されているのか? ヒアルロン酸 はどのように組織の恒常性を維持しているのか? など多くの 疑問が残されている。我々はこの総説が、ヒアルロン酸の機 能を考える上で重要な機会を提供し、その機能を理解する上 での手助けになる事を願っている。

A. はじめに

ヒアルロン酸は $N$ - アセチル - D グルコサミンと D- グルク ロン酸の 2 糖繰り返し構造からなる線状大分子ポリマー構造 の分子である (1)。ヒアルロン酸分子の 2 糖繰り返しの数は 1 万以上あり、その分子量は $10^{3}$ から $10^{4} \mathrm{kDa}$ に及ぶ。ヒアルロ ン酸は様々な組織の細胞外マトリックスの構成分子で、血管 新生、分岐形態形成、細胞の移動や分化を含む組織の制御や 恒常性維持に重要な役割を担っている (2-4)。

ヒアルロン酸は高い保水能力を持ち、細胞の分化や移動

を促進する弾性のある網目構造を形成する。ヒアルロン酸の 
properties, HA can also interact with specific cell surface receptors or binding proteins to directly regulate cell behavior. Interaction of HA with its cell surface receptor CD44 often results in the formation of stable HA-rich pericellular matrices that influence cell behavior $(4,6)$ and can directly activate intracellular signaling pathways that regulate various cellular activities (7), including tumor progression. Furthermore, HA is an important co-activator or modulator of the transforming growth factor $\beta$ (TGF- $\beta$ ) (8), bone morphogenetic protein (BMP) (9), epidermal growth factor receptor (EGFR/ErbB) (10-12), and RhoGTPase (13) signaling networks. HA also regulates a variety of cellular processes in concert with these signaling molecules.

HA is synthesized by 3 HA synthase isoforms in mammals, termed Has1, Has2, and Has3 (14-16). These 3 HA synthases show distinct expression patterns during mouse development $(16,17)$ and possess distinctly different enzymatic properties (18). Has 2 appears to play a major role in HA production during early organogenesis, because Has2null mice die at mid-gestation (E9.5-10) (19). In contrast, mice lacking Hasl or/and Has3 genes are viable and exhibit no obvious developmental abnormalities. Thus, Has 2 is a crucial synthase for HA biosynthesis in mice development.

HA has been implicated in various aspects of limb morphogenesis and is potentially involved in regulating the outgrowth and patterning of limbs. Furthermore, HA is one of the major components of the ECM and forms proteoglycan aggregates that interact with chondroitin sulfate proteoglycans and link protein (LP) in cartilage. HA draws water into the cartilage by osmosis and confers resistance to load-bearing pressure. In this review, we describe the role of HA during limb morphogenesis, which was analyzed in Has 2 conditional knockout mice crossed with Prxl-Cre mice (20). We further discuss the biochemical and genetic studies of proteoglycan aggregates, which are mainly composed of HA, aggrecan, and LP. We also focus briefly on the role of CD44, which is a major cell surface receptor of HA.

\section{B. Limb Skeletal Development}

HA-rich matrices play key roles during skeletal development. During these processes, dynamic changes in these HA-rich pericellular matrices depend on both HA synthesis and degradation. During limb development, embryonic mesenchyme emerges from the limb bud to form the basic limb primordia, and the apical ectodermal ridge (AER) strictly controls cell proliferation and migration signals. Has 2 is expressed abundantly by the AER (21) and the distal subridge mesodermal cells to provide highly hydrated paths for cell migration (22). Li et al. (21) reported that overexpression of Has 2 in chick limb mesoderm in vivo resulted in severely malformed limbs that were shortened and
いくつかの機能はその物理化学的な性質に由来していると考 えられているが、同時に特異的細胞表面レセプターや結合夕 ンパクと結合することにより細胞の挙動を制御する $(5,6)$ 。 ヒ アルロン酸の細胞表面レセプターであるCD44 との結合は、 安定したヒアルロン酸リッチな細胞周囲マトリックスを形成 し $(4,6)$ 、細胞の挙動、腫瘍の伸展のような様々な細胞活性 を制御する細胞内のシグナル経路を活性化する(7)。さらに、 ヒアルロン酸は TGF $\beta$ (8)、BMP(9)、EGFR/ErbB (10-12)、 RhoGTPases (13) シグナリングネットワークの活性化補助因子 や調節因子として重要である。

ヒアルロン酸は哺乳類ではH Has1、Has2、Has3 のヒアルロ ン酸合成酵素によって合成される(14-16)。これら 3 つのヒア ルロン酸合成酵素はマウスの発生過程に扔いて異なる発現パ ターンを示し $(16,17)$ 、また、異なる酵素学的能力を持つ $(18)$ 。 Has2 遺伝子ノックアウトマウスは、妊娠中期の胎生 $9.5 \sim 10$ 日に致死となる (19) ことから、マウスでの初期組織形成に拧 いて、Has2 遺伝子はヒアルロン酸産生の主要な役割を演じて いると考えられる。一方、Hasl もしくはHas3 のノックアウト マウスは生殖可能であり、明らかな発生異常を示さないこと から、Has2 はマウス発生でのヒアルロン酸合成に重要な合成 酵素であるといえる。

ヒアルロン酸は肢芽形成での様々な局面に関与しており、 肢芽の伸長やパターン形成を調節する能力をもつ。さらにヒ アルロン酸は細胞外マトリックスの重要な構成成分の一つで、 軟骨ではコンドロイチン硫酸プロテオグリカン、リンクタン パクと結合することによりプロテオグリカン会合体を形成す る。ヒアルロン酸はその浸透圧により軟骨へ水分を引き寄せ、 荷重圧に抗する役割を担う。この総説では、我々がP rxl-Cre トランスジェニックマウスを用い作製したHas 2 遺伝子肢芽特 異的ノックアウトマウス (20) の結果をもとに、軟骨でのヒア ルロン酸の役割について述べる。我々はさらにヒアルロン酸、 アグリカン、リンクタンパクからなるプロテオグリカン会合 体についての生化学的・遺伝学的研究について、また、ヒア ルロン酸の代表的な細胞表面レセプターである CD44 の役割 についても簡潔に述べる。

\section{B. 四肢骨格形成におけるヒアルロン酸}

ヒアルロン酸リッチマトリックスは骨格形成において重 要な役割を担う。骨格形成過程では、ヒアルロン酸リッチ細 胞周囲マトリックスでのダイナミックな変化は、ヒアルロン 酸の合成と分解によって起こる。四肢発生において、胎児の 間葉組織が四肢原基を形成するために隆起する際、外胚葉性 隆起 (AER) が厳密に細胞の分化と移動のシグナルをコント ロールしている。Has2 は外胚葉性隆起 (AER) と distal subridg 間葉系細胞により広範囲に発現され (21)、細胞移動にとっての 高湿潤環境を供給する (22)。Lin ら (21) は、Has2 遺伝子をニワ 
lacking in one or more skeletal elements. Thus, decreased HA production and downregulation of Has 2 are necessary for the formation of precartilage condensations of the limb skeletal elements that trigger further cartilage differentiation.

Because of the early mortality of Has2-null mice (19), we could not investigate in vivo function of HA during limb morphogenesis. To address this issue, we used Prx 1Cre transgenic mice to generate conditional knockout mice in which the Has 2 gene was limb bud mesoderm-specific inactivated (20). In these mutant mice, all skeletal elements in the limbs are severely shortened, and their lengths are approximately half those of the normal skeletal elements (Fig. 1). According to the histological analysis, Has 2 -deficient growth plates showed a striking reduction in hypertrophic chondrocytes and a disruption of the normal columnar structure. These results suggest that the impaired progression of chondrocyte maturation may cause a defect in the longitudinal growth of the limb skeleton. Thus, Has2-mediated HA production is essential for the normal longitudinal growth of limb skeletal elements.

In addition to the severely shortened limbs, Has2deficient mutant digits show specific skeletal patterning defects. In particular, the proximal phalanges of the 2 nd and 5th digits are duplicated in the autopods of all the Has2 mutant mice (Fig. 1). Thus, Has 2 -mediated HA production is involved in regulating the patterning of very limited portions of the digits. The fact that the duplications are limited to
トリ肢芽中胚葉で強制発現させ、その結果四肢は高度に変形、 短趾となり、一つ、もしくはそれ以上の骨格要素の欠損を示 すことを報告した。このように、軟骨発生初期におけるヒア ルロン酸産生の減少とHas 2 遺伝子の発現低下は、更なる軟骨 分化の引き金となる前軟骨凝集形成に必要不可欠である。

Has2 遺伝子ノックアウトマウスは胎生致死を示すため (19)、in vivo での四肢骨格形成におけるヒアルロン酸の機能は 不明であった。このことを解決するため、我々はPrxl-Cre 卜 ランスジェニックマウスを用いて Has 2 遺伝子を肢芽中肧葉特 異的にノックアウトしたコンディショナルノックアウトマウ

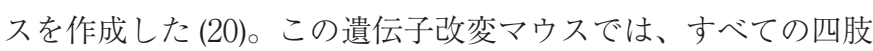
構成要素が高度に短く、そのサイズは正常マウスのお拈よそ 半分であった (図 1)。組織学的解析の結果、Has 2 遺伝子の欠 損した軟骨成長板は、肥大軟骨層の軟骨細胞の著明な減少と カラム構造の破綻を示した。これらの結果は、軟骨細胞の成 熟過程の異常が四肢骨格の長軸方向の成長を妨げているもの と推察され、Has2 遺伝子によって調整されるヒアルロン酸の 産生は、四肢骨格の正常な長軸方向成長に必要不可欠である といえる。

高度な短肢症に加え、Has 2 遺伝子の欠損した四肢では特 異的な骨格パターンの欠損が見られた。特に、第 $2 、 5$ 指の近 位基節骨は、すべてのHas 2 遺伝子改変マウスで二つに分裂し ていた(図 1)。このようにHas2 遺伝子が調節するヒアルロン 酸の産生は、指の限られた場所でのパターニングの調整にも 関与している。この指のパターニング異常は興味深いものの、

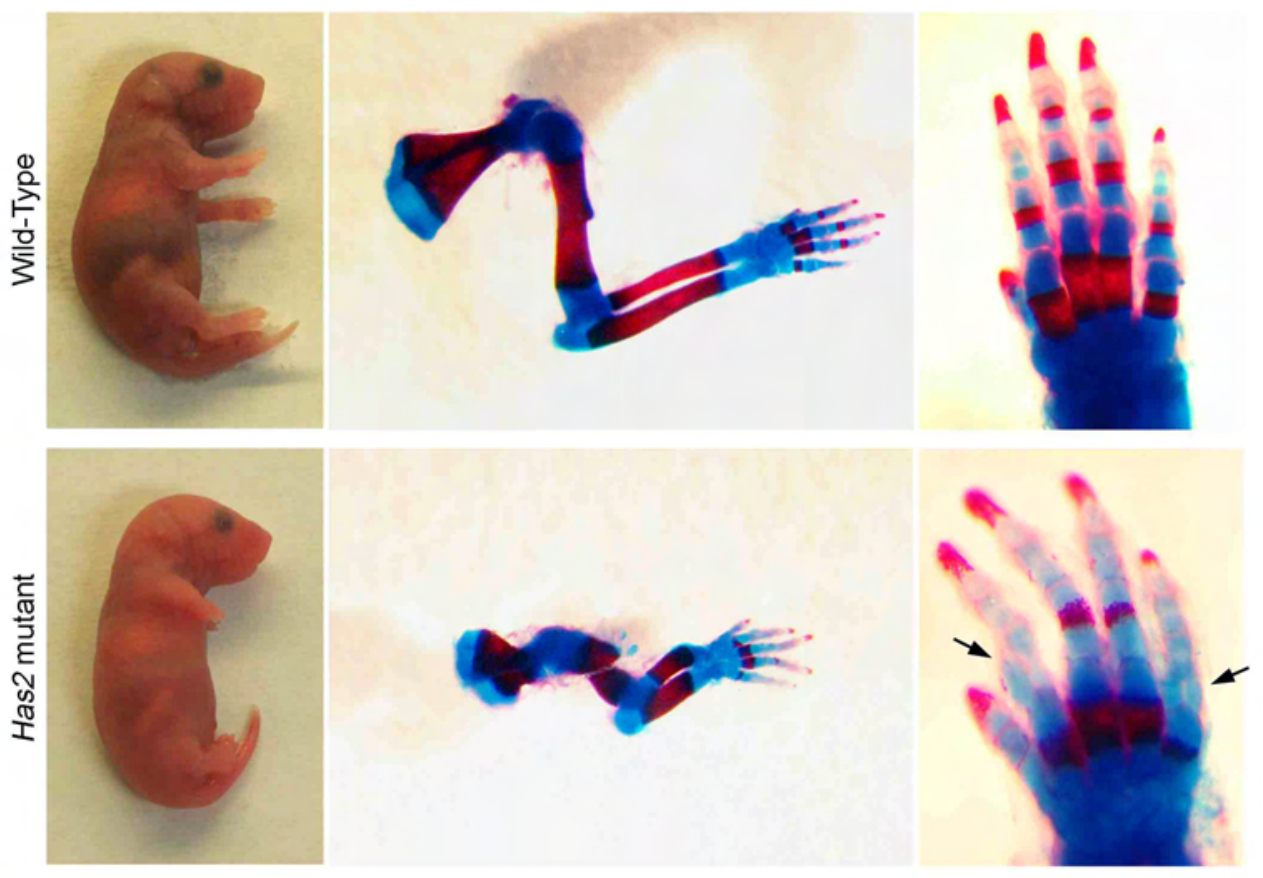

Fig.1. Has2-mediated hyaluronan production is essential for normal skeletal development. The proximal phalanges of the 2nd and 5th digits are duplicated (arrows). 
such specific digits is interesting, although the reason for this observation is still not clear.

\section{Joint Formation}

Synovial joints play a crucial role in skeletal function. Synovial joint formation is divided into multiple steps. The onset of joint formation occurs after mesenchymal condensation and can be detected as a narrow band of densely packed mesenchymal progenitor cells, which are referred to as the joint interzone $(23,24)$. The interzone is the first overt morphological sign of joint formation and is characterized by further condensation of the cells. Once the interzone is specified, the cartilage anlagen must separate to form a functional joint cavity; subsequently, the cartilaginous and synovial elements separate and form the final synovial joint (23, 24).

Several observations suggest an interaction between HA and $\mathrm{CD} 44$, which is the principal cell surface receptor of HA, in joint cavitation $(23,24)$. HA and CD44 are differentially expressed at the interzone of the joint and developing articular surfaces (25-29). It has been demonstrated that HA synthesis and CD44 expression is significantly increased in the interzone and then continues in the articular surfaces and synovium $(27,28)$. These findings indicate that, during joint formation, the local production and accumulation of HA associated with cavitation and CD44 expression in the interzone and at the developing articular surface can facilitate physical tissue separation and create fluid-filled synovial joint cavities. Dowthwaite et al. (29) reported that treatment of developing joints with exogenous HA oligosaccarides (6 disaccharide units) causes inhibition of cavitation by displacing nascent HA from its receptor. In Has2-deficient limbs, the cavitation process is defective. Distinct cavities of E16.5 Has2 mutant limbs were not present in the joint regions (20). Thus, this defective cavitation in the Has2-deficient limbs provides direct evidence of a critical role for Has2-mediated HA production in joint formation and cavitation.

\section{Growth Plate Development}

The epiphyseal ends of the growth plate form a layered structure, comprising resting, proliferative, prehypertrophic, and hypertrophic zones, and chondrocytes undergo a coordinated differentiation. The growth plate on the epiphyseal side contains a zone of rounded proliferating chondrocytes that undergo columnar differentiation processes. The cells then further differentiate into hypertrophic chondrocytes and undergo apoptosis. A variety of matrix molecules and cell signaling pathways play crucial roles in these processes (30).

We previously reported that Has2-deficient skeletal elements are severely shortened and the normal cellular architecture and relationships are perturbed (20). Has2-
その理由は現時点で不明である。

\section{C. 関節形成におけるヒアルロン酸}

関節は骨格機能において重要な役割を担う。関節形成は 多くの段階に分けられる。関節形成は間充織凝集の後に始ま り、 joint interzone と呼ばれる高濃度にパックされた間葉系未

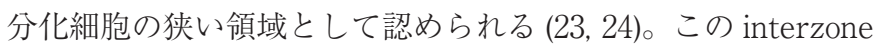
は、関節形成の最初のはっきりとした形態変化の兆候であり、 更なる細胞凝集によって特徵づけられる。一旦 interzone が決 定づけられると、軟骨原基は機能的な関節を形成するために 分離され、関節成分は最終的な関節へと形作られていく $(23$, 24)。

関節腔形成にはヒアルロン酸と、その主な細胞表面レセ プターであるCD44が関与している事がいくつかの報告によっ

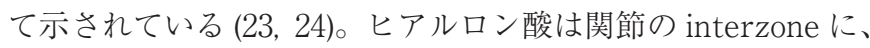
CD44 は関節表面にといった異なった発現パターンを示す $(25$ - 29)。ヒアルロン酸の合成と CD44 の発現は最初 interzone に 著明に増加し、続いて関節表面と滑膜に発現する $(27,28)$ 。こ れらの知見は、関節形成過程に置いて、関節腔形成時の局所 のヒアルロン酸の産生と蓄積、さらには関節の interzone と関 節表面での CD44 の発現は物理的な組織の分離を促進し、関 節液で満たされた関節腔を作り出す。Dowthwaiteら (29) は、 関節形成時に外部よりヒアルロン酸オリゴ糖 (6 dissacharide units)を加えると、そのレセプターから内因性のヒアルロン 酸を奪い取る事によって関節腔形成が阻害される事を示した。 Has 2 遺伝子欠損四肢では、この関節腔形成過程が障害されて いた。胎生 16.5 日の Has 2 遺伝子欠損四肢では、関節形成部 位にはっきりとした関節腔形成が認められなかった(20)。こ の事実は、Has2 遺伝子欠損四肢での関節腔形成の障害は Has2 によって産生されるヒアルロン酸が、関節および関節腔形成 に重要な働きをしているという直接的な証拠である。

\section{D. 成長板でのヒアルロン酸}

骨端部にある成長板軟骨は静止軟骨層、増殖軟骨層、肥 大軟骨層と呼ばれる層構造を成し、軟骨細胞は調和のとれた 一連の分化過程をとる。骨端側の成長軟骨板は円形状の増殖 軟骨層を含み、これらがカラム構造をなす分化過程へと進行 していく。そして、これらの軟骨細胞は、さらに肥大軟骨細 胞となり最後にアポトーシスを起こす。これらの過程では様々 なマトリックス分子や細胞シグナル伝達系が重要な役割を演 じている (30)。

我々は、Has2 遺伝子の欠損した四肢骨格は高度に短く、 正常な細胞構造やその関係が崩れている事を報告した (20)。 Has 2 遺伝子久損成長軟骨板では、細胞密度が高く、それは軟 骨細胞自身を隔てる軟骨マトリックスの減少を反映している。 


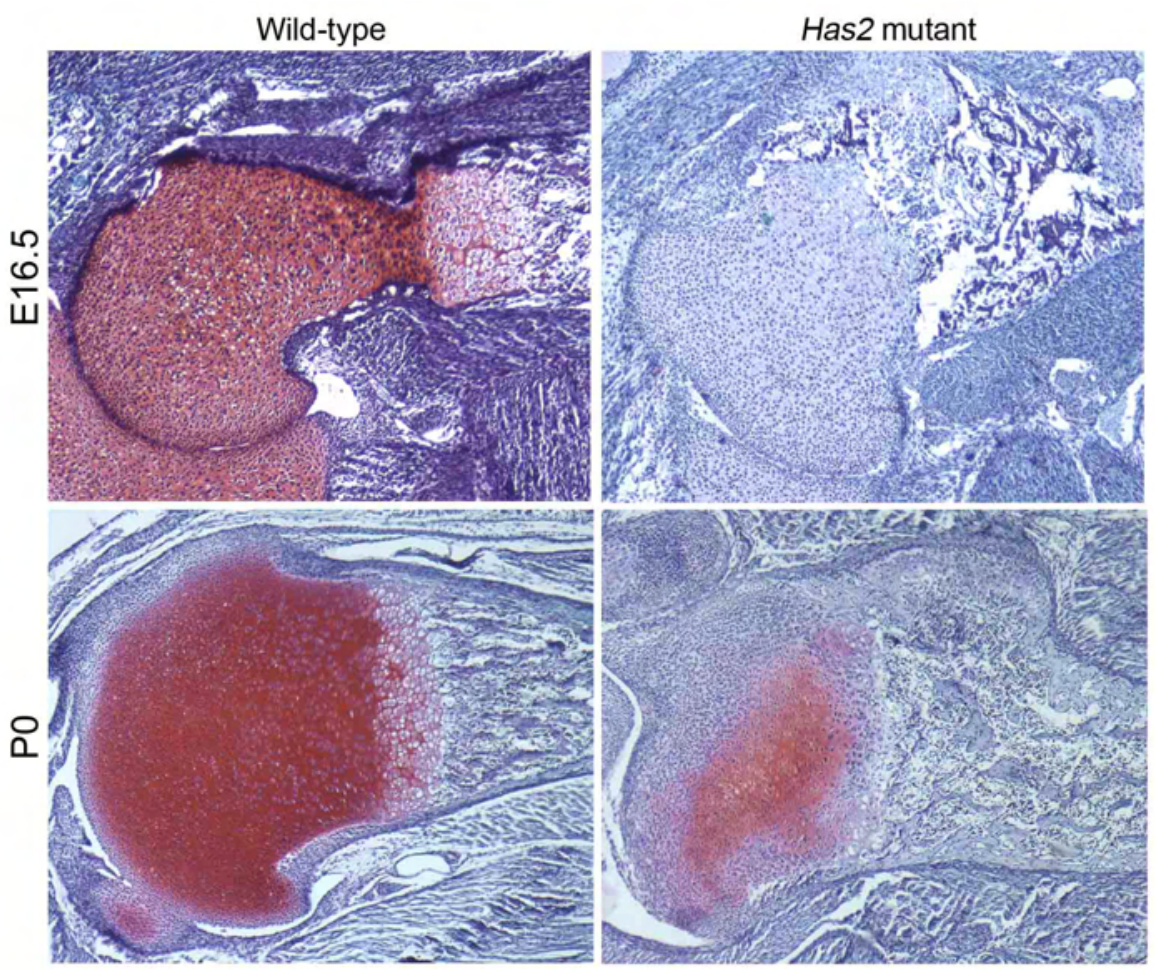

Fig. 2. Decreased deposition of proteoglycans in Has2-deficient cartilage matrix.

deficient growth plates show a considerable increase in cell density, reflecting a decreased amount of cartilage matrix separating the chondrocytes. This reduction is correlated with a strikingly decreased intensity of safranin $\mathrm{O}$ staining of glycosaminoglycans, indicating reduced deposition of proteoglycans in the cartilage matrix (Fig. 2). The decreased deposition of sulfated proteoglycans is very likely to cause a disruption of the large proteoglycan aggregates. In the normal ECM of cartilage, HA forms huge aggregates that interact with chondroitin sulfate proteoglycans and LP. The reduced formation of proteoglycan aggregates due to defective Has2mediated HA production possibly results in a decreased deposition of chondroitin sulfate proteoglycans in the matrix.

In Has2-deficient growth plates, the normal cellular relationships are perturbed. Distinct columns of flattened chondrocytes are absent and the growth plates consist of small, rounded, chondrocytes, which are randomly distributed. The formation of the columnar structure may be an important factor in longitudinal growth (31), and the disorganization and altered orientation of the chondrocytes in Has2-deficient growth plates might affect the reduction in longitudinal growth.

\section{E. Proteoglycan Aggregates in Skeletal Development}

Cartilage is a highly specialized tissue, and the major part of this tissue is a highly organized ECM. The ECM of cartilage is composed of 2 major structures, namely, collagen
この軟骨マトリックスの減少は、グリコサミノグリカン染色 に用いられるサフラニンＯの染色性の低下にもよく相関して おり、このことは軟骨マトリックスに存在するプロテオグリ カン沈着の減少を示している (図 2)。この硫酸化プロテオグリ カンの沈着減少は、ヒアルロン酸が欠損することによって大 型プロテオグリカン会合体形成が阻害されたために引き起こ されるものと思われる。正常な軟骨細胞外マトリックスでは、 ヒアルロン酸はコンドロイチン硫酸プロテオグリカン、リン クタンパクと結合することによって、巨大な会合体を形成す る。Has2 遺伝子によるヒアルロン酸産生の欠損は、このプロ テオグリカン会合体の形成を阻害し、マトリックスでのコン ドロイチン硫酸プロテオグリカンの沈着を減少させており、 これは十分可能性のある結果であった。

Has 2 遺伝子欠損成長軟骨板では、正常な細胞の相関関係 が崩れていた。カラム構造内の扁平状軟骨細胞は認められず、 小さく円形の軟骨細胞が無造作に存在していた。成長軟骨板 での秩序だったカラム構造は、長管骨の縦軸方向への成長に は重要なファクターであり (31)、このHas 2 遺伝子欠損成長軟 骨板に見られる秩序の乱れや軟骨細胞の位置関係の変化はこ のマウス長管骨の縦軸方向の成長へ影響を与えているのかも しれない。

\section{E. 骨格形成でのプロテオグリカン会合体}

軟骨は高度に分化した組織であり、その大部分は非常に 調和のとれた細胞外マトリックスが占める。軟骨の細胞外マ トリックスは 2 つ大きな成分、つまりコラーゲン䋊維構造 とプロテオグリカン会合体によって形成される(図 3)。おもに 


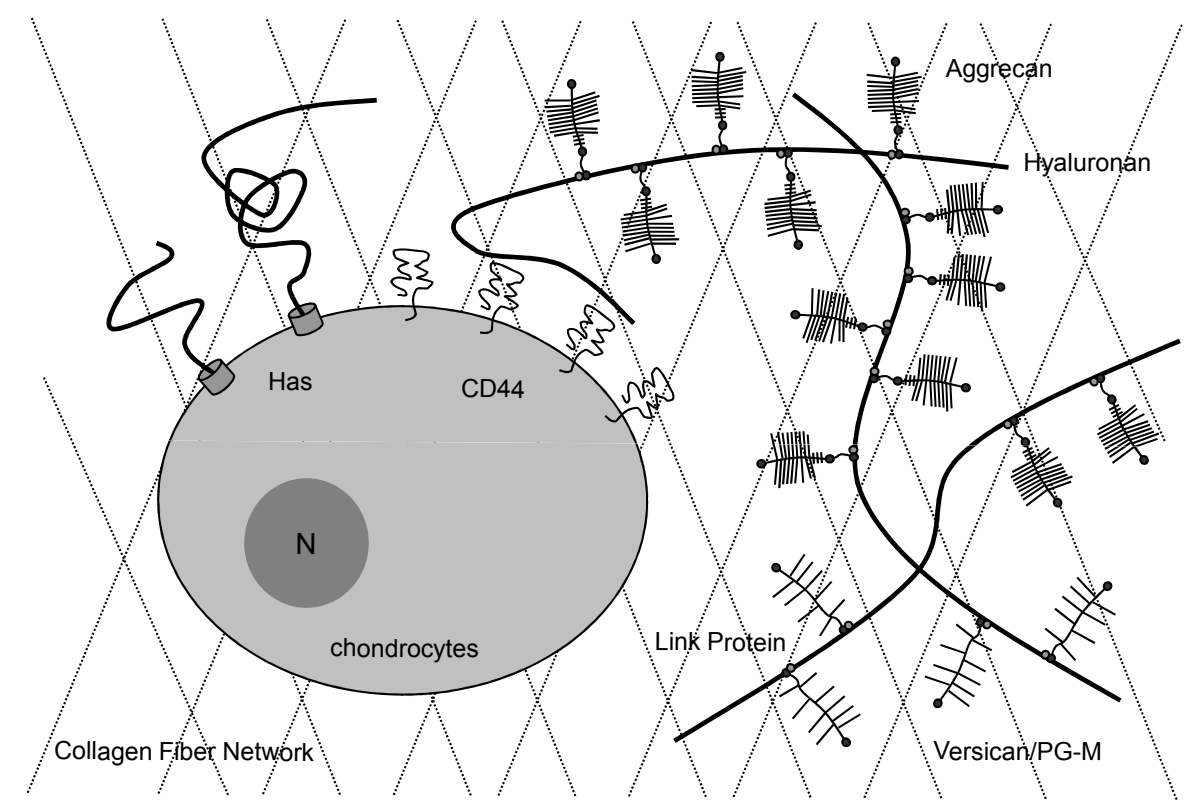

Fig. 3. Overview of the proteoglycan aggregates in cartilage. Hyaluronan is produced by hyaluronan synthase and tethered to CD44. Aggrecan and versican form proteoglycan aggregates that bind with hyaluronan and link protein. A fine network of collagen fibers (mainly types II, VI, IX, and XI) is responsible for the tensile properties.

fibers and proteoglycan aggregates (Fig. 3). Whereas a fine network of collagen fibers (mainly types II, VI, IX, and XI) is responsible for the tensile properties, the proteoglycan aggregates draw water into the cartilage by osmosis and give cartilage its unique gel-like character and resistance to load-bearing pressure. HA, proteoglycan, and LP form proteoglycan aggregates through specific interaction with each other $(32,33)$. HA plays a crucial role in the formation of proteoglycan aggregates. The disruption of proteoglycan aggregates causing severe skeletal malformation indicates that these 3 components are essential for normal cartilage growth. Furthermore, versican/PG-M aggregates are present in the articular surface area and may contribute to the distinct properties of cartilage (34).

Aggrecan is a large chondroitin sulfate proteoglycan with multiple functional domains. The core protein contains 3 globular domains, termed G1, G2, and G3. The G1 and $\mathrm{G} 2$ regions are separated by an interglobular domain (IGD), whereas the G2 and G3 regions are separated by 2 glycosaminoglycan (GAG) attachment domains, keratan sulfate (KS), and chondroitin sulfate (CS). The N-terminal G1 domain binds to both HA and LP. The G1 domain can be divided into 3 functional domains, named $\mathrm{A}, \mathrm{B}$, and $\mathrm{B}^{\prime}$. The A subdomain is responsible for the interaction with LP, and a segment of B-B' can bind to HA (Fig. 4) (35). Mutations in the aggrecan gene cause chondrodysplasias in humans (36, 37), mice (38), fowl (39), and cattle (40). In humans, a single base pair insertion within the variable repeat region of exon
II 型、VI 型、IX 型、XI 型で構成されるコラーゲン繊維の整っ た構造は、軟骨へ伸張能力を与え、一方、プロテオグリカン 会合体は、その浸透性により軟骨内へ水分を引き寄せる。そ してそのユニークなジェル様の性質を軟骨へ与え、軟骨は荷 重圧へ耐えうるようになる。ヒアルロン酸、プロテオグリカン、 リンクタンパクは扔互いに特異的な結合を介してプロテオグ リカン会合体を形成する $(32,33)$ 。ヒアルロン酸はこのプロテ オグリカン会合体形成に重要な役割を果たす。プロテオグリ カン会合体の破綻は、重度の骨格形成異常を引き起こすこと から、これら 3 つの構成要素は正常な軟骨の発育に必要不可 欠である。さらに、バーシカン $/ \mathrm{PG}-\mathrm{M}$ 会合体が関節表面に 存在し、この会合体が軟骨で何らかの特別な役割を演じてい る可能性がある (34)。

アグリカンは多くの機能的ドメインを持つ大型のコンド ロイチン硫酸プロテオグリカンで、そのコアタンパクは G1、 G2、G3 と呼ばれる3つの球状ドメインを持つ。G1 と G2 領域 はインターグロブラードメイン (IGD) によって隔てられてお り、G2、G3 領域はケラタン硫酸 (KS)、コンドロイチン硫酸 (CS) の 2 つのグリコサミノグリカン付着ドメインによって区別さ れている。 $\mathrm{N}$ 末端の $\mathrm{G} 1$ ドメインはヒアルロン酸とリンクタン パクの両方に結合する。G1 ドメインは A、B、B'という3つ のサブドメインにわけることができる。 $\mathrm{A}$ サブドメインはリ ンクタンパクと結合し、B-B' 領域はヒアルロン酸と結合する ことができる (図 4) (35)。アグリカン遺伝子の異常はヒト (36、 37)、マウス (38)、ニワトリ (39)、ウシ (40) に軟骨形成不全症を 引き起こす。人の場合、エクソン 12 の可変繰り返し領域に 1 
12 introduces a frameshift and causes spondyloepiphyseal dysplasia (SED)(36). Spondyloepimetaphyseal dysplasia (SEMD), which is a recessive skeletal disorder, shows homozygosity for a missense mutation in the aggrecan G3 domain (37). In cartilage matrix deficient ( $c m d$ ) mice, which are a natural knockout of the aggrecan gene, a 7-bp deletion in exon 5 introduces a frameshift resulting in a premature termination codon in exon 6 (38). Although $\mathrm{cmd}$ cartilage shows normal levels of collagen type II and LP, biochemical and immunological studies have revealed defects in the synthesis of the aggrecan core protein (41). The cartilage of cmd mice appears as tightly packed chondrocytes with small amounts of matrix, which is very similar to the matrix seen in the cartilage of Has2-deficient mice.

The growth plates of Has2-deficient skeletal bones are severely shortened and disorganized. The decreased amount of cartilage matrix separating the chondrocytes causes a considerable increase in cell density. The reduced formation of proteoglycan aggregates due to lack of HA possibly results in a decreased deposition of aggrecan in the matrix. The disorganization of Has2-deficient growth plates might be a secondary consequence of the perturbation of aggrecan aggregates in the cartilage matrix.

LP contains a structural analogue of the aggrecan G1 domain, which possesses $\mathrm{A}, \mathrm{B}$, and $\mathrm{B}$ ' subdomains, and belongs to the family of HA-binding proteins. Whereas the A subdomains of both aggrecan G1 and LP are thought to interact with each other, a stretch of B-B' is responsible for the interaction with HA (Fig. 4). $L P$ knockout mice exhibit
塩基対の挿入があり、その結果フレームシフトが抗こり脊椎・ 骨端異形成症 (SED:spondyloepiphyseal dysplasia) を引き起こ す (36)。劣性遺伝の骨格形成異常症である春椎・骨端・骨幹端 異形性症 (SEMD:spondylometaepiphyseal dysplasia) は、アグ リカン G3 ドメインのミスセンス遺伝子異常によって引き起こ されることが報告されている (37)。自然発症型のアグリカン遺 伝子ノックアウトマウスである $c m d$ マウスは、エクソン 5 の 7 塩基対の欠損のため、早期の終止コドンがエクソン 6 に挿入 されている (38)。cmd マウスの軟骨は、正常な II 型コラーゲ ンとリンクタンパクの発現を示すものの、生化学的、免疫学 的検討では、アグリカンのコアタンパクの合成が久如してい ることが示された(41)。cmd マウスの軟骨では、Has2 遺伝子 欠損軟骨マトリックスで見られるような、マトリックスがほ とんどない高密度にパックされた軟骨細胞が認められた。

Has 2 遺伝子久損マウスの成長軟骨板は、非常に短く障害 されている。軟骨細胞を分離する軟骨マトリックスの減少が、 軟骨での細胞密度をあげる原因と考えられる。ヒアルロン酸 の減少によって、プロテオグリカン会合体の形成が減少し、 その結果、マトリックスでのアグリカンの沈着が減少したの であろう。Has2 遺伝子久損マウスの成長軟骨板の障害は、軟 骨マトリックスでのアグリカン会合体の形成阻害のために起 こった 2 次的な現象の可能性がある。

リンクタンパクは、アグリカン G1 ドメインと類似構造を 持ち、A、B、B' のサブドメインを有する。また、リンクタ ンパクはヒアルロン酸結合タンパクに属する。A サブドメイ ンは、アグリカンの G1 ドメインとリンクタンパクの両者は A サブドメインを介してお互いに結合する一方、ヒアルロン酸 とはB-B' セグメントで結合する(図 4)。リンクタンパクのノッ
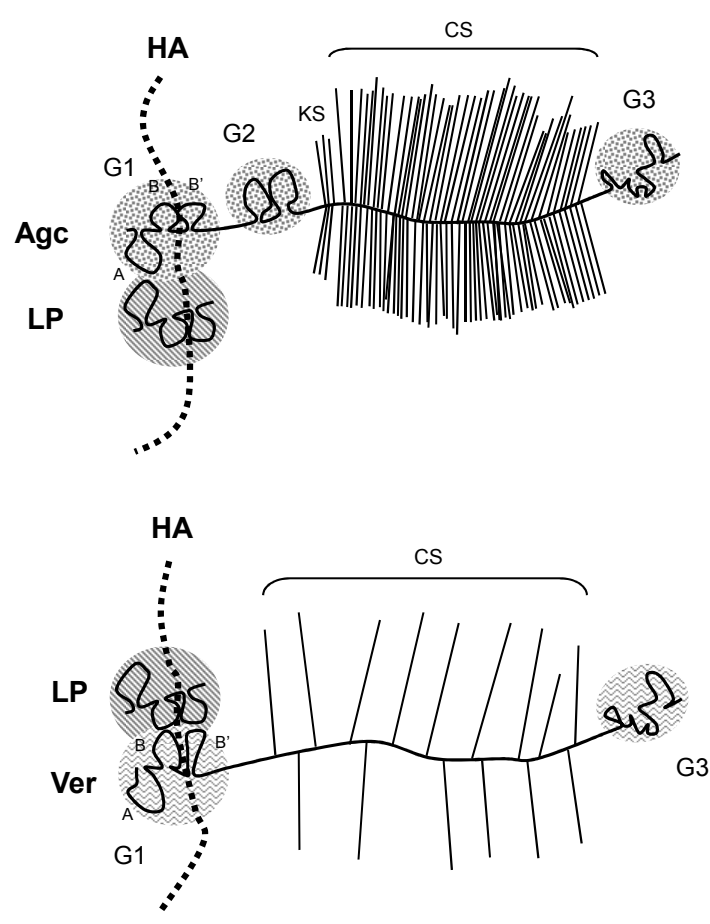

Fig. 4. The proteoglycan aggregates in cartilage. Aggrecan aggregates are composed of aggrecan (Agc), hyaluronan (HA), and link protein (LP). The A subdomain is responsible for the interaction with $\mathrm{LP}$, and a segment of B-B' can bind to HA. Versican/PG-M (Ver) can bind to both HA and LP through the B-B' segments of the G1 domain in a different manner to the aggrecan G1 domain. 
dwarfism and craniofacial abnormalities, and their long bones are shortened (42). Histological examination of $L P$ knockout mice showed that the columnar structures of the chondrocytes in the growth plate are disorganized, and the lack of LP affects chondrocyte differentiation from prehypertrophic to hypertrophic zones. The decreased deposition of aggrecan in $L P$ knockout cartilage confirms the crucial role played by LP in the deposition of aggrecan aggregates. Thus, HA, aggrecan, and LP form aggrecan aggregates through specific interactions and the aggrecan aggregates are essential for the normal organization of the growth plate.

Versican/PG-M is a large chondroitin sulfate proteoglycan of the aggrecan family and consists of G1 and G3 globular domains and 2 CS domains (CS- $\alpha$ and CS- $\beta$ ) (43). The N-terminal G1 domain of versican consists of 3 looped subdomains, termed A, B, and $\mathrm{B}^{\prime}$. Versican can bind to both HA and LP through the B-B' segments of the G1 domain, although in a manner different to the aggrecan G1 domain (Fig. 4) (33). During cartilage development, versican is expressed transiently at a high level in the condensed mesenchymal area and is rapidly degraded. Several studies (44-46) have reported that versican functions to create an extracellular environment conducive to mesenchymal condensation. In adult cartilage, versican is mainly localized in the interterritorial area of the articular surface, whereas aggrecan stains rather diffusely in the territorial area of prehypertrophic chondrocytes (34). Furthermore, versican aggregates are present in the articular surface area and may provide ECM properties distinct from the deeper areas where aggrecan aggregates are abundantly distributed. Further studies are required to understand the in vivo function of versican aggregates and the relationship between HA and versican in cartilage.

\section{F. Function of HA in Osteoarthritis}

The remodeling and turnover of cartilage matrix components must be carefully regulated to maintain the biomechanical properties of the tissue. It has long been known that HA potentiates the physical properties of the stroma such as lubrication and/or viscoelasticity. The metabolic activity of chondrocytes in adult cartilage is adapted to maintain the composition of a functional ECM. The collagen network is metabolically inert, whereas the removal of aggrecan aggregates from the ECM (47) is in balance with the synthesis and deposition of new molecules. However, under osteoarthritic conditions, this metabolic balance is disrupted, and episodes of increased catabolism (48) and increased synthesis (49) of matrix molecules occur. Although most of osteoarthritic cartilage samples contain proteoglycan species, the capacity for aggregate formation is much lower and HA levels are reduced (50). Furthermore, a decreased KS/CS ratio and an elevation of chondroitin-4-sulfate levels are observed クアウトマウスは、dwarfism と頭部顔面の異常を示し、長管 骨は短くなっている。リンクタンパクノックアウトマウスの 組織学的解析では、軟骨成長板の軟骨カラム構造は障害され、 そのリンクタンパクの欠損が前肥大軟骨層から肥大軟骨層の 軟骨細胞へ影響を与えていた。リンクタンパクノックアウト マウス (42)では、アグリカンのマトリックスへの沈着が減少 しており、このことは、リンクタンパクがアグリカン会合体 の組織への沈着に重要な役割を演じていることを指し示して いる。以上のように、ヒアルロン酸、アグリカン、リンクタ ンパクはそれぞれの特異的な結合を介してアグリカン会合体 を形成し、その会合体は正常な軟骨成長板の維持に必要不可 欠であるといえる。

バーシカン/PG-M はアグリカンファミリーに属する大 型のコンドロイチン硫酸プロテオグリカンで、G1、G3 の球状 ドメインと 2 つコンドロイチン硫酸結合ドメイン (CS- $\alpha$ 、 CS- $\beta$ ) を有する (43)。N 末端の G1 ドメインは、A、B、B' の 3 つのサブドメインからなる。バーシカンはアグリカンと は異なり、G1 ドメインの B-B' セグメントを介してヒアルロ ン酸、リンクタンパクと結合する (図 4) (33)。軟骨の発生過程 に置いてバーシカンは間充織凝縮領域に一過性に強く発現し、 その後急速に消失する。いくつかの研究(44-46)によれば、バー シカンは間充織凝縮への助けとなる細胞外環境を作り出す機 能があるのではと推察されている。成体の軟骨では、アグリ カンは前肥大軟骨領域にびまん性に存在するが、バーシカン はおもに関節表面の間質領域に存在する (34)。さらにバーシカ ン会合体は、関節表面に存在することが知られており、アグ リカン会合体がより梁部に広く存在することから、これらの 違いは、バーシカン会合体は細胞外マトリックスへ何らかの 異なる機能を有するものと考えられる。更なる研究が、生体 内での軟骨に扔けるバーシカン会合体の機能、そしてヒアル ロン酸とバーシカンの関係を明らかにすることであろう。

\section{F. 関節軟骨でのヒアルロン酸の機能}

軟骨マトリックス構成要素のリモデリングと代謝は、そ の生体力学的な機能を維持するために注意深く制御されなけ ればならない。ヒアルロン酸はその生理学的な特性から、間 質の潤滑油的な性質と粘弾性を与えるものとされてきた。成 人軟骨での軟骨細胞の代謝活性は、機能的な細胞外マトリッ クスを維持するように調整されている。コラーゲンネットワー クの代謝調節は非常に遅く、一方アグリカン会合体は新たに 産生される分子の合成と沈着のバランスをとりながら、細胞 外マトリックスで代謝される(47)。しかしながら、変形性関 節症の状況下では、この代謝調節のバランスが崩れ、代謝と 合成の充進が認められる $(48,49)$ 。変形性関節症の軟骨組織の ほとんどはプロテオグリカンを含んでいるが、その会合体形 成能力は非常に低く、ヒアルロン酸レベルも低下しているこ とがわかっている(50)。さらにケラタン硫酸/コンドロイチン 硫酸の割合の変化やコンドロイチン 4 硫酸の上昇が報告され ている (51)。これらマトリックス分子の衰失は、MMPや AD- 
(51). This loss of matrix molecules may be due to increased degradation via elevated matrix metalloproteinases (MMPs), disintegrin and metalloprotease with thrombospondin motif (ADAMTS) activity, inhibition of biosynthesis, and/or a decreased retention of proteoglycans due to deficits in HA.

HA binding to CD44 plays a primary role in retaining and anchoring the proteoglycan aggregates to the surface of chondrocytes $(52,53)$. Furthermore, CD44 also participates in the internalization and turnover of HA in articular chondrocytes $(54,55)$. Disruption of the HA-CD44 interaction may disturb cartilage homeostasis and lead to pathological conditions such as observed in osteoarthritis. HA fragments induce the production of MMPs in macrophages (56) and the degradation of cartilage (57). These observations indicate that uncoupling endogenous HA from chondrocytes by disruption of the HA-CD44 interactions results in a catabolic effect mediated by HA oligosaccharide fragments (57). Intraarticular injections of high molecular weight hyaluronic acid may have chondroprotective effects in osteoarthritis models (58) and are given to reduce the pain in osteoarthritis patients (59). These results suggest that during osteoarthritis HA oligosaccharides may have different effects on chondrocytes compared with full-length HA. Much is known about the function of HA, but many unanswered questions still surround the function of HA in adult cartilage, including the treatment of osteoarthritis. In the near future, using our Has2-conditional knockout mice, we hope to gain a further understanding of the function of $\mathrm{HA}$ in adults.

\section{G. Conclusion}

In this mini review, we have briefly summarized the role of HA in cartilage. HA is a simple molecule composed of $\mathrm{N}$-acetyl-D-glucosamine and D-glucuronic acid, and is a structural component in various tissues. HA plays a key role in tissue organization and homeostasis, not only through its physicochemical properties but also by interacting with binding proteins and specific cell surface receptors. Although much is known about the function of HA, many questions remain to be answered about how HA is regulated. Future studies using other Cre transgenic mice (i.e., Col2alCre, GDF5-Cre) will provide clearer insights into the function of HA.

\section{Acknowledgements}

I would like to thank Profs. Yu Yamaguchi and Robert A. Kosher for the studies of Has 2 conditional knockout mice, and Profs. Koji Kimata and Hideto Watanabe for the analysis of proteoglycan aggregates.
AMTS 活性上昇による分解の克進やマトリックス分子の生合 成の低下、そしてヒアルロン酸量低下によるプロテオグリカ ンの組織沈着の減少によるものであろう。

CD44 へ結合しているヒアルロン酸は軟骨細胞表面へプロ テオグリカン会合体をとどめておく重要な働きを演じている (52, 53)。さらに、CD44 は関節軟骨でのヒアルロン酸の内在化 と代謝に寄与している $(54,55)$ 。ヒアルロン酸と CD44 の結合 の破綻は、軟骨の恒常性の破綻を招き、変形性関節症で認め られるような病的な状態を招くのかもしれない。実際、ヒア ルロン酸フラグメントはマクロファージの MMPs の産生を招 き (56) 、軟骨の変性を引き抗こす (57)。これらの事実は、ヒ アルロン酸とCD44 の結合の破綻によって軟骨細胞から産生さ れた内因性のヒアルロン酸が、ヒアルロン酸オリゴ糖によって 誘導されるカタボリック効果を引き起こした結果である (57)。 分解されていないヒアルロン酸は、変形性関節症モデルでは 軟骨保護作用を有し (58) 、ヒアルロン酸の関節腔内注射は変 形性関節症患者での痛みを軽減することが知られている (59)。 これらの結果は変形性関節症下では、ヒアルロン酸オリゴ糖 が全長のヒアルロン酸と比較して異なる作用を有することを 指し示している。ヒアルロン酸については多くのことが知ら れているが、変形性関節症の治療を含む成人軟骨でのヒアル ロン酸の機能には多くの疑問が残されている。近い将来、我々 のHas2 コンディショナルノックアウトマウスを用いて、ヒア ルロン酸の成人軟骨での役割の更なる理解が得られるかもし れない。

\section{G. 結 語}

この総説では、我々は軟骨でのヒアルロン酸の役割につい て簡潔にまとめた。ヒアルロン酸は $N$-アセチル -D グルコサミ ンと D-グルクロン酸からなる単純な分子であり、様々な組織 の構成要素である。ヒアルロン酸はその物性だけでなく、ヒ アルロン酸結合タンパクや細胞表面レセプターを介して組織 の調節と恒常性の維持に重要な役割を演じている。ヒアルロ ン酸の機能は多くのことが知られているが、ヒアルロン酸が どのように調節されているのかなど多くのことが未解決のま まである。更なる研究がヒアルロン酸機能のより良い理解を もたらすであろう。

\section{謝辞}

筆者はHas2 コンディショナルノックアウトマウスの解析 について山口祐教授、ならびに Robert A. Kosher 教授に感謝 の意を表します。また、プロテオグリカン会合体の解析につ いて、木全弘治教授、渡辺秀人教授に感謝の意を表します。 


\section{References}

1. Meyer, K., and Palmer, J. W. (1934) J. Biol. Chem. 107, 629-634.

2. Gakunga, P., Frost, G., Shuster, S., Cunha, G., Formby, B., and Stern, R. (1997) Development 124, 3987-3997.

3. Weigel, P. H., Hascall, V. C., and Tammi, M. (1997) J. Biol. Chem. 272, 13997-4000.

4. Toole, B. P., Wight, T. N., and Tammi, M. I. (2002) J. Biol. Chem. 277, 4593-4596.

5. Toole, B. P. (1997) J. Intern. Med. 242, 35-40.

6. Toole, B. P. (2001) Semin. Cell Dev. Biol. 12, 79-87.

7. Turley, E. A., Noble, P. W., and Bourguignon, L.Y. (2002) J. Biol. Chem. 277, 4589-4592.

8. Bourguignon, L. Y., Singleton, P. A., Zhu, H., and Zhou, B. (2002) J. Biol. Chem. 277, 39703-39712.

9. Peterson, R. S., Andhare, R. A., Rousche, K. T., Knudson, W., Wang, W., Grossfield, J. B., Thomas, R. O., Hollingsworth, R. E., and Knudson, C. B. (2004) J. Cell Biol. 166, 1081-1091.

10. Bourguignon, L. Y., Zhu, H., Chu, A., Iida, N., Zhang, L., and Hung, M. C. (1997) J. Biol. Chem. 272, $27913-27918$.

11. Camenisch, T. D., Schroeder, J. A., Bradley, J., Klewer, S. E., and McDonald, J. A. (2002) Nat. Med. 8, 850-855.

12. Tsatas, D., Kanagasundaram, V., Kaye, A., and Novak, U. (2002) J. Clin. Neurosci. 9, 282-288.

13. Bourguignon, L. Y. (2001) J. Mammary Gland Biol. Neoplasia. 6, 287-297.

14. Itano, N., and Kimata, K. (1996) J. Biol. Chem. 271, 9875-9878.

15. Watanabe, K., and Yamaguchi, Y. (1996) J. Biol. Chem. 271, 22945-22948.

16. Spicer, A. P., and McDonald, J. A. (1998) J. Biol. Chem. 273, 1923-1932.

17. Tien, J. Y., and Spicer, A. P. (2005) Dev. Dyn. 233, 130-141.

18. Itano, N., Sawai, T., Yoshida, M., Lenas, P., Yamada, Y., Imagawa, M., Shinomura, T., Hamaguchi, M., Yoshida, Y., Ohnuki, Y., Miyauchi, S., Spicer, A. P., McDonald, J. A., and Kimata, K. (1999) J. Biol. Chem. 274, 25085-25092.

19. Camenisch, T. D., Spicer, A. P., Brehm-Gibson, T., Biesterfeldt, J., Augustine, M. L., Calabro, A. Jr, Kubalak, S., Klewer, S. E., and McDonald, J. A. (2000) J. Clin. Invest. 106, 349-360.

20. Matsumoto, K., Li, Y., Jakuba, C., Sugiyama, Y., Sayo, T., Okuno, M., Dealy, C. N., Toole, B. P., Takeda, J., Yamaguchi, Y., and Kosher, R. A. (2009) Development 136, 2825-2835.

21. Li, Y., Toole, B. P., Dealy, C. N., Kosher, R. A. (2007) Dev. Biol. 305, 411-420.

22. Kosher, R. A, and Savage, M. P. (1981) Nature 291, 231-232.

23. Archer, C. W., Dowthwaite, G. P., and Francis-West, P. (2003) Birth Defects Res. C Embryo Today 69, 144-155.

24. Pacifici, M., Koyama, E., and Iwamoto, M. (2005) Birth Defects Res. C Embryo Today 75, 237-248.

25. Craig, F. M., Bayliss, M. T., Bentley, G., and Archer, C. W. (1990) J. Anat. 171, 17-23.

26. Archer, C. W., Morrison, H., and Pitsillides, A. A. (1994) J. Anat. 184, 447-456.

27. Edwards, J. C., Wilkinson, L. S., Jones, H. M., Soothill, P., Henderson, K. J., Worrall, J. G., and Pitsillides, A. A. (1994) J. Anat. 185, 355367.

28. Pitsillides, A. A., Archer, C. W., Prehm, P., Bayliss, M. T., and Edwards, J. C. (1995) J. Histochem. Cytochem. 43, $263-273$.

29. Dowthwaite, G. P., Edwards, J. C., and Pitsillides, A. A. (1998) J. Histochem. Cytochem. 46, 641-651.

30. Kronenberg, H. M. (2003) Nature 423, 332-336.

31. Karsenty, G., and Wagner, E. F. (2002) Dev. Cell. 2, 389-406.

32. Watanabe, H., Cheung, S. C., Itano, N., Kimata, K., and Yamada, Y. (1997) J. Biol. Chem. 272, 28057-28065.

33. Matsumoto, K., Shionyu, M., Go, M., Shimizu, K., Shinomura, T., Kimata, K., and Watanabe, H. (2003) J. Biol. Chem. 278, 41205-41212.

34. Matsumoto, K., Kamiya, N., Suwan, K., Atsumi, F., Shimizu, K., Shinomura, T., Yamada, Y., Kimata, K., and Watanabe, H. (2006) J. Biol. Chem. 281, 18257-18263.

35. Watanabe, H., and Yamada, Y. (2002) Glycoconj. J. 19, 269-273.

36. Gleghorn, L., Ramesar, R., Beighton, P., and Wallis, G. (2005) Am. J. Hum. Genet. 77, 484-490.

37. Tompson, S. W., Merriman, B., Funari, V. A., Fresquet, M., Lachman, R. S., Rimoin, D. L., Nelson, S. F., Briggs, M. D., Cohn, D. H., and Krakow, D. (2009) Am. J. Hum. Genet. 84, 72-79.

38. Watanabe, H., Kimata, K., Line, S., Strong, D., Gao, L. Y., Kozak, C. A., and Yamada, Y. (1994) Nat. Genet. 7, $154-157$.

39. Landauer, W. (1965) J. Hered. 56, 209-214.

40. Cavanagh, J. A., Tammen, I., Windsor, P. A., Bateman, J. F., Savarirayan, R., Nicholas, F. W., and Raadsma, H. W. (2007) Mamm. Genome. 18, 808-814.

41. Kimata, K., Barrach, H. J., Brown, K. S., and Pennypacker, J. P. (1981) J. Biol. Chem. 256, 6961-6968.

42. Watanabe, H., and Yamada, Y. (1999) Nat. Genet. 21, 225-229.

43. Shinomura, T., Zako, M., Ito, K., Ujita, M., and Kimata, K. (1995) J. Biol. Chem. 270, 10328-10333.

44. Williams, D. R. Jr, Presar, A. R., Richmond, A. T., Mjaatvedt, C. H., Hoffman, S., and Capehart, A. A. (2005) Biochem. Biophys. Res. Commun. 334, 960-966.

45. Kamiya, N., Watanabe, H., Habuchi, H., Takagi, H., Shinomura, T., Shimizu, K., and Kimata, K. (2006) J. Biol. Chem. 281, $2390-2400$.

46. Shepard, J. B., Gliga, D. A., Morrow, A. P., Hoffman, S., and Capehart, A. A. (2008) Anat. Rec. (Hoboken) 291, 19-27.

47. Sandy, J. D., Flannery, C. R., Neame, P. J., and Lohmander, L. S. (1992) J. Clin. Invest. 89, 1512-1516.

48. Lohmander, L. S., Neame, P. J., and Sandy, J. D. (1993) Arthritis Rheum. 36, 1214-1222.

49. Cs-Szabó, G., Melching, L. I., Roughley, P. J., and Glant, T. T. (1997) Arthritis Rheum. 40, 1037-1045.

50. Rizkalla, G., Reiner, A., Bogoch, E., and Poole, A. R. (1992) J. Clin. Invest. 90, 2268-2277.

51. Plaas, A. H., West, L. A., Wong-Palms, S., and Nelson, F. R. (1998) J. Biol. Chem. 273, 12642-12649.

52. Knudson, W., Aguiar, D. J., Hua, Q., and Knudson, C. B. (1996) Exp. Cell. Res. 228, 216-228.

53. Knudson, C. B., Nofal, G. A., Pamintuan, L., and Aguiar., D. J. (1999) Biochem. Soc. Trans. 27, $142-147$.

54. Hua, Q., Knudson, C. B., and Knudson, W. (1993) J. Cell. Sci. 106, 365-375.

55. Aguiar, D. J., Knudson, W., and Knudson, C. B. (1999) Exp. Cell. Res. 252, 292-302.

56. Horton, M. R., Shapiro, S., Bao, C., Lowenstein, C. J., and Noble, P. W. (1999) J. Immunol. 162, 4171-4176. 
57. Knudson, W., Casey, B., Nishida, Y., Eger, W., Kuettner, K.E., and Knudson, C.B. (2000) Arthritis Rheum. 43, $1165-1174$.

58. Takahashi, K., Hashimoto, S., Kubo, T., Hirasawa, Y., Lotz, M., and Amiel, D. (2001) J. Orthop. Res. 19, $500-503$.

59. Jüni, P., Reichenbach, S., Trelle, S., Tschannen, B., Wandel, S., Jordi, B., Züllig, M., Guetg, R., Häuselmann, H. J., Schwarz, H., Theiler, R., Ziswiler, H.R., Dieppe, P.A., Villiger, P. M., and Egger, M.; Swiss Viscosupplementation Trial Group. (2007) Arthritis Rheum. 56, 36103619 .

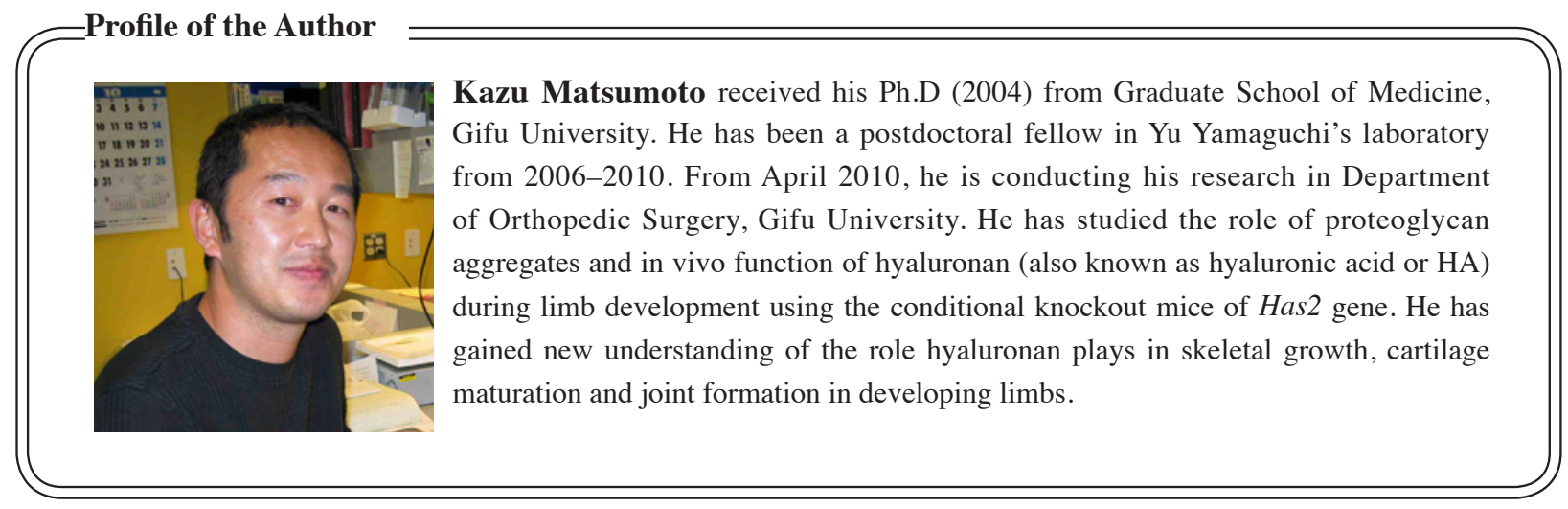

